\title{
UM LIBELLUS EPIGRAMMATON NA CHAMADA CASA DE PROPÉRCIO
}

\author{
Évelyne Prioux ${ }^{* 1}$
}

\begin{abstract}
RESUMO: Cet article propose une analyse du cycle de vignettes mythologiques retrouvées dans la maison dite de Properce à Assise. Les peintures présentent la particularité d'être accompagnées d'épigrammes inscrites qui mettent en jeu de nombreuses réminiscences littéraires inspirées d'Homère, de Pindare, de Théocrite, d'Ovide et peut-être de Properce. La datation des peintures interdit d'assigner l'origine de ce décor à Properce lui-même, mais les motifs choisis suggèrent, tout comme les épigrammes, la présence d'une intention métapoétique dans la constitution de ce décor qui juxtapose des images du pouvoir du chant et des illustrations du servitium amoris. Il faut donc bien, malgré l'écart chronologique qui sépare la réalisation des peintures des années où vécut le poète élégiaque, considérer que ce décor témoigne de la volonté de rendre hommage au célèbre poète d'Assise.
\end{abstract}

PALAVRAS-CHAVE: Poesia Helenística, Intertextualidade, Casa de Propércio.

A chamada "Casa de Propércio" está localizada em Assis, sob a Igreja de Santa Maria Maior, onde ela foi descoberta no século dezenove. Escavações posteriores começaram no final da década de 1940 com a intervenção de um time local de arqueólogos amadores, que descobriram um corredor ou criptopórtico, mas cuja escavação jamais foi completada por medo de que afetasse a estabilidade da igreja medieval.

O corredor descoberto na década de 1940 é adornado com afrescos: um fundo amarelo ocre com motivos branco candelabro. Essas paredes amarelas também foram realçadas por uma série de pequenas vinhetas pintadas com uma técnica a tempera, depois de os afrescos terem secado completamente. Como essas vinhetas não foram terminadas no mesmo tempo dos afrescos, elas são muito frágeis e muitas delas tinham desaparecido no momento de sua descoberta.

A escavação levou à descoberta de dezesseis vinhetas, dez das quais estão acompanhadas de epigramas gregos gravados na argamassa do afresco das paredes².

\footnotetext{
* Pesquisadora do Centre National de la Recherche Scientifique.

${ }^{1}$ A pesquisa para este artigo, que era inicialmente parte da minha tese de doutorado (Prioux, 2004), foi publicada com um escopo diferente em Prioux, 2008 (b), parte 1, capítulo 2, onde enfatizei os aspectos arqueológicos e artístico-históricos da pinacotheca de Assis. Um estudo independente da mesma casa foi publicado por M. Squire (2009). Eu gostaria de expressar aqui minha gratidão a A. Rouveret e K. Gutzwiller por seu encorajamento e sugestões em versões anteriores deste trabalho. Ele foi apresentado, na ocasião, durante uma conferência não publicada intitulada Poesia Grega na Itália, organizada por A. Sens e J. Osgood em Fiésole, Villa Le Balze/Georgetown University (junho de 2007); sou grata a A. Sens, J. Osgood e a todos os participantes da conferência por seus comentários gentis e por sua ajuda. Também gostaria de expressar minha gratidão a J. Baracat Jr. por receber este artigo na coleção que preparava e por oferecer-se gentilmente para traduzi-lo.

${ }^{2}$ Cf. Kerényi, 1952; Ciotti - Pietrangeli, 1958; Guarducci, 1953, 1977 e 1979; SEG XXX, 1135-1144; Gallavotti, 1980; Medaglia, 1981; Veyne, 1983, pp. 24 e 221, n. 3; Guarducci 1986a, 1986b, e 1986c; Medaglia, 1987; Giangrande, 1991 e 1997; Leach, 1992; Strazzulla, 1994; Manca/Scaleggi/Vergoni, 2003; Coarelli, 2004, pp. 105-106; Cairns, 2006, p. 29; Bulloch, 2006. 
Encontrar epigramas ou citações poéticas inscritas perto de pinturas é muito raro: alguns exemplos são conhecidos de Pompéia e outros sítios, tais como Roma, Óstia e Otford (Reino Unido) $^{3}$. Que essa descoberta excepcional tenha acontecido em Assis, terra natal de Propércio, imediatamente sugeriu uma relação entre esses epigramas e o poeta. Até meados de 1980, pensava-se que a casa era a casa de Propércio, e pensava-se que os epigramas eram do punho de Propércio. Na realidade, é improvável que os afrescos amarelos pertençam a um período tão antigo. Pinturas da segunda metade do primeiro século d.C. fornecem bons comparantes, e os pavimentos encontrados nas salas vizinhas são típicos da era flaviana ${ }^{4}$. De um ponto de vista literário, essa datação seria consistente com o uso de dísticos: se excetuamos dois dísticos (N4 e N1) ${ }^{5}$, todos os epigramas encontrados no corredor são monodísticos ${ }^{6}$.

As vinhetas que realçavam os afrescos amarelos eram todas, aparentemente, enquadradas por listras vermelhas a fim de sugerir a aparência de pequenos pinakes. Embora muitas vinhetas já estivessem apagadas na época de seu descobrimento, é possível imaginar a localização de algumas das vinhetas perdidas graças aos traços de tinta vermelha que ainda podem ser vistos nas paredes. Antes de prosseguirmos, devemos notar que provavelmente se pretendia que essa série de pequenos pinakes sugerisse o aspecto geral de uma galeria de arte ou pinakotheka. As várias vinhetas eram apresentadas em pequenos quadros, exatamente como os painéis de madeira pintados para ser vistos pendurados nas paredes das galerias de arte reais. A coleção de epigramas, portanto, estava ligada a uma coleção de pinturas, e o corredor combinava uma pequena antologia poética com uma galeria de arte. Eu argumentarei que essas coleções foram concebidas como um conjunto de objetos poéticos e visuais dotado de sentido: não apenas cada uma das peças do quebra-cabeça carrega um sentido próprio, mas também um simbolismo e uma significação gerais podem emergir da análise da coleção como um todo.

\section{A ESTRUTURA DA COLEÇÃO}

Um levantamento geral das descobertas nos ajudará a entender a estrutura e o sentido globais dessa coleção dupla de imagens e epigramas. As vinhetas pintadas formam uma série de pares que respondem uns aos outros de uma parece à outra, embora ocasionalmente uma vinheta simplesmente esteja defronte a uma estrutura arquitetônica.

Ao longo do corredor, parece haver uma alternância regular entre painéis quadrados e retangulares. Os painéis coloridos são ricamente coloridos, ao passo que os painéis retangulares usam uma gama de cores muito mais limitada, consistindo basicamente de azul, branco e marrom. Essa alternância regular cria um efeito de variação e de ritmo que era provavelmente percebida da melhor maneira pelo espectador ao atravessar o corredor de uma ponta à outra.

As partes do corredor que foram trazidas à luz também eram separadas em três áreas diferentes por estruturas arquitetônicas. A parede norte é, com efeito, interrompida

\footnotetext{
${ }^{3}$ Para um catálogo, cf. Prioux, 2004. Epigramas também eram usados para comentar os retratos dos uiri illustres.

${ }^{4}$ Em minha opinião, os sectilia encontrados nessa casa deveriam ser comparados aos exemplos Flavianos de Pompéia e Óstia estudados por Guidobaldi, 2001, 361-362. Contra, veja-se Coarelli, 2004, n. 27.

$5 \mathrm{~N}$ refere-se à parede norte do corredor e $S$, à sul; os números referem-se aos epigramas, partindo-se do Leste para o Oeste (veja-se a tabela no final deste artigo).

${ }^{6}$ Cf. Lausberg, 1982; Laurens, 1989, 285-306. Os epigramas dísticos parecem corresponder a uma tendência poética que começou sob Nero e se desenvolveu nas décadas seguintes.
} 
por uma pequena êxedra adornada com afrescos representando pássaros entre ramos floridos. As estruturas arquitetônicas, assim, criam um impulso de observar as pinturas de uma maneira mais estática, como três unidades separadas.

\section{As vinhetas da asa oeste}

Os restos da asa oeste do corredor não parecem apresentar nenhum epigrama. Nessa área, as vinhetas pintadas estão todas severamente danificadas e seus tópicos não podem ser identificados. O mau estado de preservação das pinturas da asa oeste nos impede de propor qualquer interpretação acerca de seu sentido geral.

\section{As decorações da área central}

Como foi dito acima, um recesso ou êxedra interrompe a parede norte e seus afrescos amarelos. As três paredes desse recesso são adornadas com uma predela negra e uma zona branca central preenchida com ramos floridos, pássaros de várias espécies e pétalas em forma de coração. Na parede sul, janelas-aberturas (S8 e S11) foram construídas ficarem defronte às paredes laterais do recesso norte. Entre as janelas, ainda podemos ver os restos de duas vinhetas pintadas, como as outras, com uma técnica $a$ tempora, no fundo amarelo dos afrescos: o painel S9 é uma vinheta retangular monocromática com listras de pintura branca que não são mais legíveis. O painel S10 também está severamente danificado, mas ainda temos um epigrama que indica o tema da imagem:

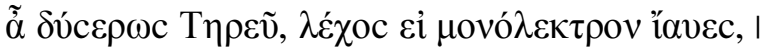

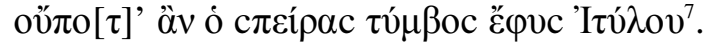

Ah! Tereu, infeliz no amor! Se tivesses dividido a cama com apenas uma mulher, jamais terias, pai dele, te tornado o túmulo de Ítilo ${ }^{8}$.

É interessante que essa pintura foi usada como um berloque para um afresco que representa todos os tipos de pássaros num trilho de flores e galhos floridos. A localização da vinheta, assim, lembraria ao leitor as metamorfoses de Tereu, Procne e Filomela, que foram transformados em pássaros: uma poupa, uma andorinha e um rouxinol. Entretanto, o mito de Tereu não era um motivo comum nas artes visuais. Conhecemos apenas três representações desse mito na arte romana, incluindo a pintura de Assis ${ }^{9}$. As raras imagens que são consideradas relacionadas a esse mito referem-se todas ao contexto dionisíaco do mito. Especificamente, Procne e Filomela são mostradas como mênades furiosas, uma característica que corresponde à narrativa de Ovídio, na qual a vingança das duas irmãs ocorre durante um festival dionisíaco ${ }^{10}$.

À primeira vista, a unidade das decorações da área do recesso está na presença de mitos e imagens envolvendo pássaros. Como veremos, o elemento dionisíaco pode ser importante porque constitui um elemento de continuidade temática entre essa área e a asa leste.

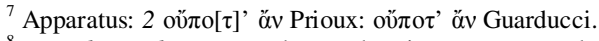

${ }^{8}$ Nota do Tradutor: as traduções das citações gregas e latinas são feitas a partir da tradução para o inglês oferecida pela autora, a fim de preservar suas opções.

${ }^{9}$ Veja-se Touloupa, LIMC VII/1 (1994), cat. nr. 16. O catálogo de Touloupa deveria ser completado com as pinturas encontradas na Casa dei Cei (Pompeii, ins. I, 6, 15, triclinium [g]): Michel 1990, 36-40, 77-78; Pompei. Pitture e Mosaici, I, pp. 408-409, 440449, esp. 408 [de Vos]. 


\section{As decorações da asa leste: a parede norte}

Há três pontos notáveis no esquema geral das paredes da asa leste: o efeito da composição anelar (ring composition); a disposição simétrica das pinturas na parede norte; e a possibilidade de ligar uma pintura da parede norte à sua contraparte na parede sul. As pinturas da parede norte envolvem sucessivamente: Polifemo e Galatéia, a carruagem de Apolo, a infância de Íamo, uma representação desconhecida mas central (talvez Polifemo pastoreando suas cabras), Mársias, Baco e a pantera, e, finalmente, um pastor mítico (talvez Orfeu?). Uma análise básica desses tópicos nos permite pensar que as várias pinturas representavem personagens ligados aos dois deuses da poesia - Apolo e Dioniso.

A primeira vinheta representa Polifemo e Galatéia:

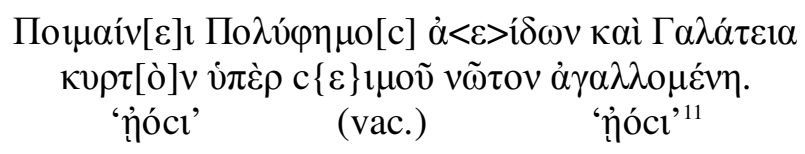

Polifemo e Galatéia pastoreiam seus rebanhos: ele canta e ela se exibe no dorso curvado da besta de nariz arrebitado

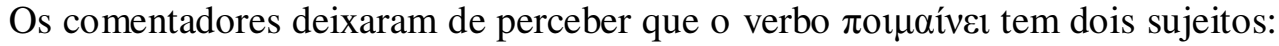
Polifemo, que pastoreia suas ovelhas e cabras, e Galatéia, que pastoreia um rebanho de golfinhos (uma metáfora similar era conhecida para Proteu, o pastor de focas) ${ }^{12}$.

Galatéia, que era uma ninfa do mar, teria sido facilmente associada com as sugestões dionisíacas do mar de tíasos. Nesse quadro surpreendente, os personagens não são representados como figuras em pé, mas como máscaras. Em minha opinião, os melhores comparantes para essa imagem são fornecidos por uma série de relevos esculpidos na segunda parte do primeiro século d.C.: os chamados Maskenreliefs mitológicos, que eram parte do aparato decorativo de algumas casas italianas no início do Império e que freqüentemente representam máscaras de personagens mitológicos deitados na praia ou nas costas de golfinhos ${ }^{13}$. Nesses relevos, as máscaras são sempre situadas sobre pilhas de pedras ou rochas e cercadas de atributos e animais (cabras, ovelhas e golfinhos) representados numa escala menor dos que as máscaras. Como outros Maskenreliefs, os Maskenreliefs mitológicos eram comumente associados a representações dionisíacas e começaram a desenvolver-se na era augustana; Polifemo e Galatéia aparecem em alguns poucos relevos datados da segunda metade do primeiro século d.C. Um desses relevos, encontrado em Nemi, mostra a máscara de Galatéia montando o dorso de um pequenino golfinho; a Nereida está avançando na direção da máscara do Ciclope, que está deitado na praia sobre uma pilha de rochas. A vinheta de Assis deriva dessa tradição de imagens.

O segundo retrato da parede norte, uma carruagem puxada por grifos ${ }^{14}$, evidentemente se relaciona a Apolo. Eis o epigrama:

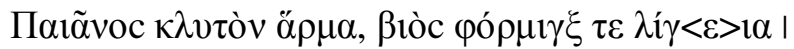

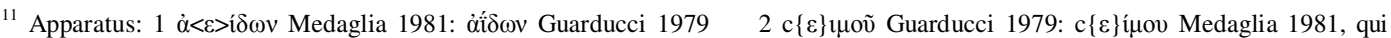
c<i $>\mu$ ov edidit, quo nomine censet genus aliquod piscium significari 3 recte interpretatus est additamenta Medaglia 1981.

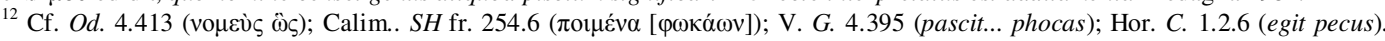
Cf. também Thomas, 1986.

${ }^{13}$ Cf. Pailler, 1971; e Cain, 1988, 107-221

${ }^{14}$ Compare-se com Tran Tam Tinh, 1974, 42-44, fig. 21; e com Reinach, 1922, 347, figures 6, 9.
} 


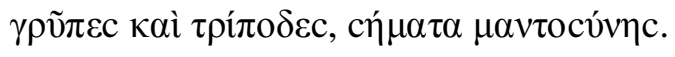

Famoso carro de Péon, arco e melodiosa fórminx; grifos e trípodes, símbolos de adivinhação. colorida:

A terceira vinheta ainda apresenta vários remanentes de uma pintura ricamente

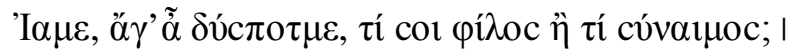

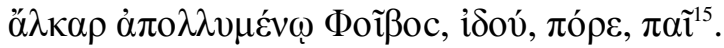 \\ Vem, Íamo, ó criança desafortunada! De que te servem os pais e amigos? \\ Mas olha, minha criança! Febo te enviou alívio, quando morrias.
}

Embora a pintura seja agora ilegível, o epigrama indica que era uma representação da infância de Íamo. Não conhecemos nenhuma outra descrição dessa cena nas artes visuais. Suas aparições na poesia são quase igualmente raras: com exceção do pequeno epigrama em Assis, o mito foi tratados apenas na sexta ode Olímpica de Píndaro ${ }^{16}$. Íamo, o fundador do oráculo olímpico e filho de Apolo, foi abandonado por sua mãe Evadne; o bebê teria morrido, se seu pai não lhe tivesse enviado duas cobras para alimentá-lo com mel. Quando Evadne dava à luz Íamo, Épito, seu pai adotivo, foi a Delfos para descobrir a identidade do pai da criança. Quando Épito voltou de Delfos, anunciando que o bebê era filho de Apolo e que se tornaria um vate famoso, o bebê foi procurado na floresta onde sua mãe o abandonara. Ele foi encontrado em uma cama de flores chamadas ió (violetas ou amores-perfeitos). $\mathrm{Na}$ sexta Olímpica, Píndaro joga com as várias explicações etimológicas do nome de Íamo: é provável que essa ode etiológica e etimológica tenha despertado o interesse do epigramatista desconhecido de Assis. Ademais, a ode pindárica é caracterizada por uma quantidade de notações pictóricas relativas às cores, efeitos de luz e reflexos. É provável que a sugestão pictórica da ode pindárica tenha inspirado a vinheta. Assim, pareceria que esse retrato era uma composição original criada como uma homenagem à poesia de Píndaro.

A quarta vinheta da parede norte, isto é, o painel central da asa leste, provavelmente era um dos maiores elementos do ciclo pictorial. Embora a pintura esteja severamente danificada, ainda é possível distinguir duas cabras ou ovelhas na sua metade esquerda. A inscrição nessa vinheta, uma citação da Ilíada (7. 264), não fornece muita ajuda para a reconstrução do significado da pintura:

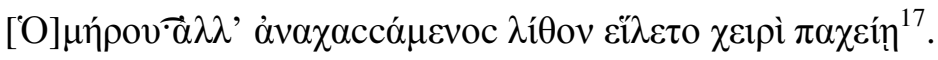

Por Homero: mas, retrocedendo, agarrou uma pedra com sua mão forte.

A linha é retirada do duelo entre Hector e Ájax: Hector agarra uma pedra para atirá-la em Ájax, então Ájax faz o mesmo. Um pouco depois, os guerreiros são

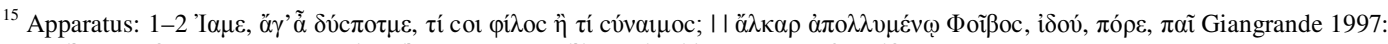

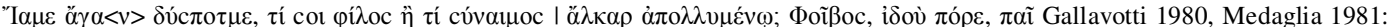

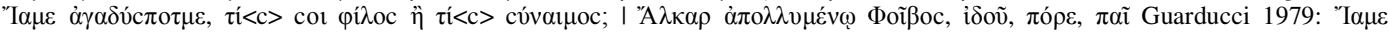

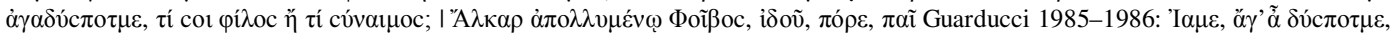

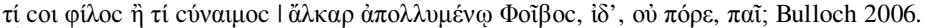

${ }^{16}$ Pind. O. 6.29-57.

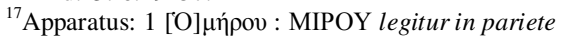


separados por dois mensageiros. Essa inscrição levanta dois problemas específicos: primeiro, alguém procurou apagar essa linha na Antiguidade; segundo, ela foi cancelada por duas linhas incisadas no afresco. Dificilmente podemos descobrir qual poderia ter sido a relação entre a linha e os animais mostrados na pintura, e talvez a linha tenha sido cancelada porque não se sentia que ela completasse a imagem de uma maneira apropriada. Em contraste, Guarducci (1979) sugere que a pintura não representava a batalha entre Hector e Ájax, mas a loucura de Ájax. Contudo, os animais parecem ainda estar em pé e vivos. Eu, portanto, sugeriria que nós deveríamos pensar em outra cena envolvendo animais, uma cena que forneceria razões mais convincentes para escolher uma linha que envolvia o gesto específico de agarrar uma pedra e atirá-la. A idéia de um famoso pastor de cabras atirando pedras com sua mão enorme pode nos levar a pensar em Polifemo arremessando rochas imensas na nau de Odisseu ${ }^{18}$. Se for assim, a vinheta central também representava uma cena que envolvia Polifemo.

Embora a seguinte vinheta seja ilegível, o epigrama indica que a pintura se relacionada com o mito de Mársias:

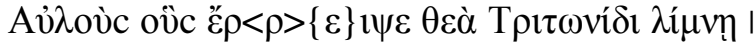

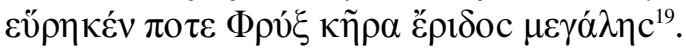

$$
\begin{aligned}
& \text { As flautas que a deusa jogara no lago Tritônis } \\
& \text { um frígio uma vez encontrou - destino de grande querela }
\end{aligned}
$$

O dístico alude à estória de Atena inventando a flauta e jogando-a no lago Tritônis, depois de ter visto seu próprio reflexo na água. A flauta foi, então, encontrada por Mársias, o sátiro que desafiou Apolo num certame musical. Assim, como a segunda e a terceira vinhetas da mesma parede, o tema dessa pintura concernia a Apolo.

A vinheta seguinte foi inteiramente perdida e nós conhecemos apenas duas palavras do epigrama:

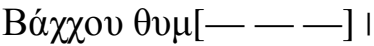

$$
\begin{aligned}
& \pi \alpha ́ \rho \delta \alpha \lambda ı \text { ENNOC }[-\ldots-]
\end{aligned}
$$

A vinheta era obviamente um berloque para a imagem dos grifos de Apolo, e a pantera bem poderia estar puxando uma carruagem repleta de atributos báquicos ${ }^{20}$.

A última vinheta na série também é um mistério: parece que o epigrama N1 consistia de uma única linha. Eu não consegui encontrar os restos dessa inscrição in situ. Ele pode ter se perdido no terremoto de 1997 e minha leitura, portanto, baseia-se na de Guarducci e em uma fotografia fornecida pela Soprintendenza. A fotografia não exibe nenhum traço de palavras perdidas ou letras perdidas, mas, no entanto, o epigrama está certamente incompleto:

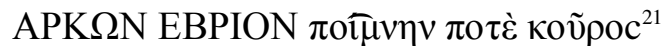

\footnotetext{
${ }^{18}$ Od. 9. 508-512.

${ }^{19}$ Apparatus: $\kappa \tilde{\rho} \rho \alpha$ legitur in tectorio: $\kappa \tilde{\lambda} \lambda \alpha$ prop. Gallavotti

${ }^{20}$ Para tais imagens, veja-se Reinach 1912, III, 183, nr. 2; 359, nr. 3); Turcan 1966, 449-450.

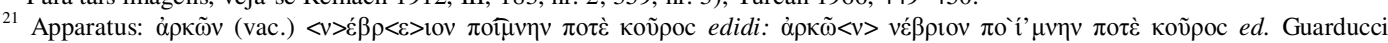

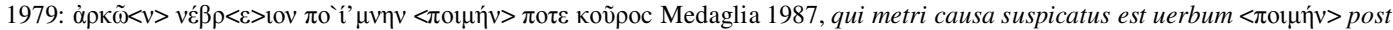

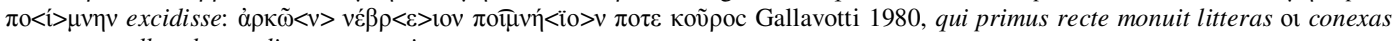
esse neque ullam harum litterarum omissam esse.
} 
(Ele que era) uma vez um rapaz tentando evitar o rebanho de Hebro (?)

Uma vez, quando era um rapaz, ele era suficiente [...] o rebanho de Hebro.

O metro não está correto e o sentido também não é satisfatório. Traduzi ع̌ $\beta \rho ı v$ por "de Hebro" sem nenhuma certeza. Na verdade, não conhecemos nenhuma outra ocorrência do adjetivo eßpıov. Guarducci 1979 sugeriu que o adjetivo deveria ser

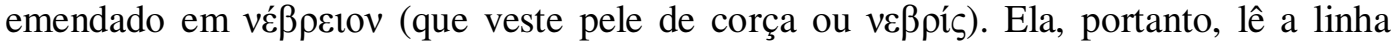
como uma alusão à morte de Penteu: Penteu tentava evitar o rebanho de corças, isto é, as mênades. Se essa hipótese estiver correta, haveria uma forte relação entre essa imagem e a vinheta represetando Tereu: ambas as pinturas se refeririam ao poder de Dioniso e evocam a estória infeliz de um filho desmembrado por sua mãe e tia(s).

Mas essa leitura da vinheta supõe que nós emendemos a leitura a leitura de

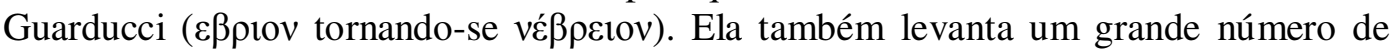
problemas: por que Penteu deveria ser apresentado como um кoũpoc? Por que ele deveria ser comparado a um pastor? Talvez devamos, em vez disso, tentar interpretar

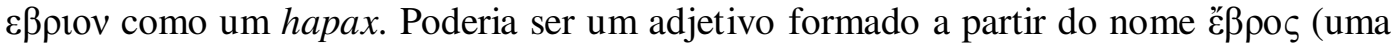
palavra rara que se refere ao bode) ou "E $\beta \rho \rho_{\text {( }}$ (o rio trácio Hebro)? Se for assim, a pintura poderia ter sido uma representação de Orfeu, talvez Orfeu encantando os animais $\left(\pi \circ \alpha_{\mu} \nu \eta\right)$. A conexão entre Orfeu e o rio Hebro era bem conhecida, com certeza: depois que o poeta foi desmembrado pelas mênades trácias, sua cabeça e sua lira flutuavam no rio Hebro e, finalmente, atravessaram o mar até chegarem à costa da Metimna, a terra mãe da poesia lírica ${ }^{22}$. A bem da verdade, uma alusão à morte de Orfeu e ao modo como sua cabeça e sua lira flutuaram até chegarem à costa da Metimna teria formado uma contraparte interessante para a imagem da máscara de Polifemo deitado na praia próximo a uma lira. Também deveríamos notar que a vida de Orfeu estava conectada tanto com Apolo quanto com Dioniso.

Como foi sugerido por Richard Hunter ${ }^{23}$, o epigrama N1 poderia ser uma citação de um poema perdido: o único outro epigrama de uma linha na série, N4, é de fato uma citação da Ilíada. O advérbio $\pi$ o $\tau \varepsilon ́$ pode mesmo sugerir que N1 era de fato a linha de abertura de um poema perdido ${ }^{24}$. Outras hipóteses foram aventadas durante a discussão: como foi notado por E. Bowie, APK $\Omega N$ pode ser uma lição corrompida de $\alpha \rho \kappa \tau \omega v$ (de ursos). Se for assim, poder-se-ia estar tentado a emendar a forma incerta EBPION em

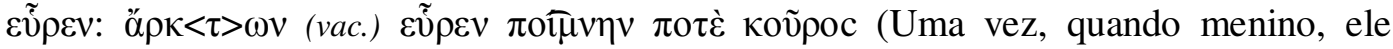
encontrou um rebanho de ursos). O vacat poderia ser preenchido com palavras esquecidas, e.g. $<\dot{\varepsilon} v \not ̋ v v \tau \rho ı$. Tal lição nos permitiria identificar um terceiro Polifemo em N1, visto que Teócrito menciona os filhotes de urso que o Ciclope cria com a

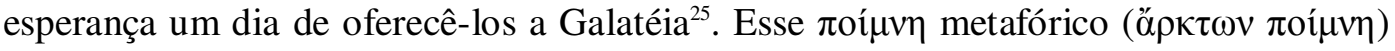
forneceria uma ótima contraparte para o rebanho metafórico de Galatéia em N7, o "rebanho" de golfinhos. Especulativas como essas hipóteses possam ser, elas também tendem a mostrar que não deveríamos confiar demais em qualquer identificação de N1, uma vez que a inscrição estava aparentemente corrompida demais desde o começo. Os únicos pontos firmes são que N1 trata de um garoto ou jovem, e que concerne a algum tipo de pastor, talvez o pastor de um rebanho metafórico.

${ }^{22}$ Cf. Fánocles, fr. 1.11-12 Powell; Ov. M. 11.50-60.

${ }^{23}$ Em comunicação oral durante um congresso.

${ }^{24}$ Cf. Calim. Hecale fr. 1 Hollis

${ }^{25}$ Teocr. 11,41 . 


\section{A parede sul}

Apenas dois epigramas sobrevivem na parede sul. O primeiro se situa sob uma vinheta concebida como um berloque de uma representação da infância de Íamo. Mesmo que a pintura esteja totalmente destruída, seu tema pode facilmente ser adivinhado pela leitura do epigrama:

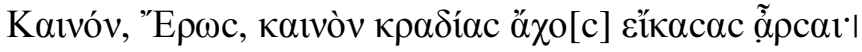

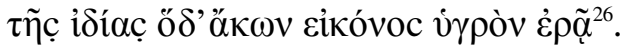

É um novo, sim, um novo tormento que tu inventaste para o coração encharcar-se, Eros. Apesar de si mesmo, este homem definha com amor por sua própria imagem.

O pequeno poema brinca com a metáfora de Eros como um pintor: Eros forjou

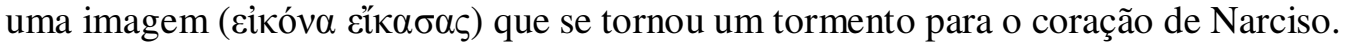

Imagens de Narciso contemplando seu próprio reflexo parecem ter se tornado muitíssimo populares nas decorações domésticas da segunda metade do primeiro século. Em pinturas pompeianas, o reflexo do herói é freqüentemente reduzido à aparência de uma cabeça vista na água. Se esse era o caso da pintura de Assis, a imagem teria sido visualmente relacionada às máscaras de Polifemo e Galatéia: em ambos os casos, o espectador teria visto uma cabeça flutuando na água. Ambas as pinturas também apresentavam a peculiaridade de focalizar o motivo da contemplação à beira da água: Polifemo contemplava Galatéia, assim como Narciso ao seu próprio reflexo. O tema do reflexo e das imagens em espelhos também estava presente no mito de Mársias e Atena: foi depois de olhar para seu próprio reflexo na água que a deusa lançou a flauta no lago Tritônis.

A imagem de Narciso também tinha forte relação com a pintura de Íamo, que era sua contraparte imediata: Íamo devia seu nome à flor, ao passo que Narciso dera seu nome a uma flor.

O último epigrama da série é a contraparte do epigrama N3 (as flautas de Mársias). Esse dístico indica que a pintura S3 representava Hércules na corte de Ônfale, rainha da Lídia, com quem o herói permaneceu por três anos como escravo. Ele também alude à vida efeminada que Hércules levava nessa corte, usando vestuário feminino e fiando lã:

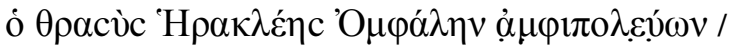

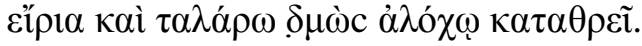

$$
\text { 'ov } \varepsilon v^{\prime 27}
$$

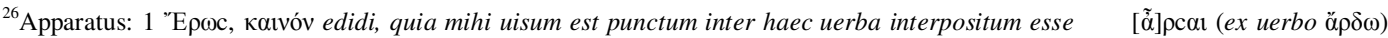
recte interpretata mihi uidetur Guarducci 1985-1986, quae adseuerauit se uestigia litterae A in imagine photographica agnouisse

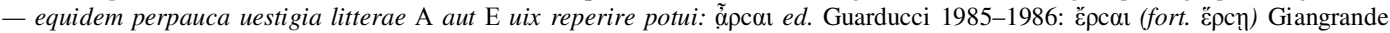

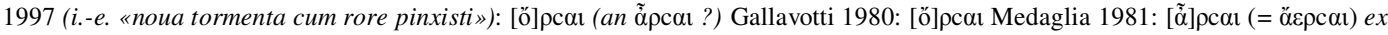

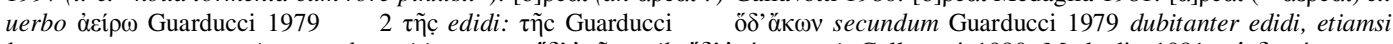

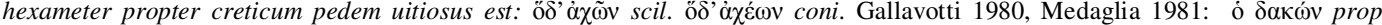
Medaglia 1987, ed. Bulloch 2006 (the "biter" has been bitten): haud probabilia uidentur cetera uerba a Medaglia proposita

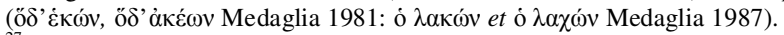

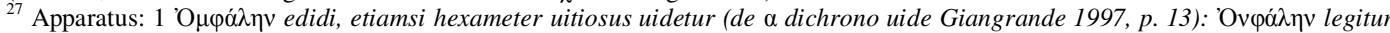

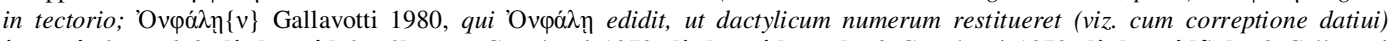

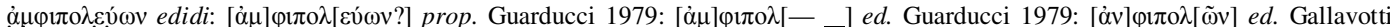

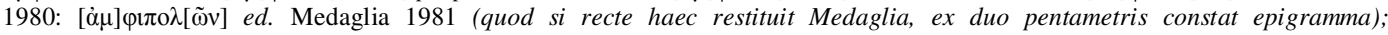

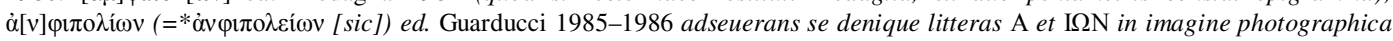

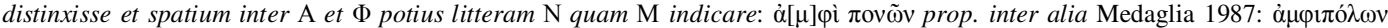

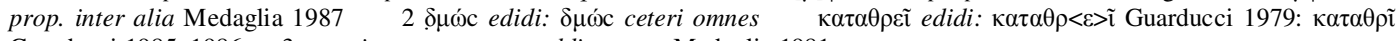
Guarducci 1985-1986 3 recte interpretatus est additamenta Medaglia 1981.
} 
Embora aconteça de o mito de Hércules e Ônfale ser um tópico comum na arte romana, conhecemos apenas algumas pouquíssimas imagens em que Hércules cuida da lã e de cestos de trabalho ${ }^{28}$. Uma pintura pompeiana perdida envolvendo um personagem que segura um tirso e um tambor claramente mostra as sugestões dionisíacas desse tipo de $\operatorname{cenas}^{29}$. Enquanto a imagem de Hércules com fuso é muito rara na arte visual, ela é muitíssimo comum na poesia e aparece tanto nas Elegias de Propércio quanto nas Heroides de Ovídio: uma vez mais, parece que o dono da casa selecionava uma cena fortemente relacionada com os textos poéticos e tinha possivelmente mandava criarem uma nova pintura para o propósito do seu ciclo pictorial $^{30}$.

UMA CELEBRAÇÃO DA POESIA: POETAS E INTERTEXTUALIDADE NOS EPIGRAMAS DE ASSIS

Como notamos, as cenas pictórias da asa leste estão ligadas a Dioniso ou a Apolo, os dois deuses da poesia. Algumas imagens também se conectam com poemas famosos: incertos como seus conteúdos possam ser, a pintura N4, a imagem central da parede norte, se associa à citação da Ilíada. Homero, portanto, figura no centro desse ciclo de epigramas e pinturas programáticas. Um outro exemplo é fornecido pela representação da infância de Íamo (N5): uma cena assim necessariamente evocaria Píndaro e a sexta ode olímpica. Identificada a alusão pindárica de N5, é possível pensar que o epigrama N3 (as flautas de Atena), o berloque de N5 dentro da Ringkomposition da parede norte, também alude a Píndaro, uma vez que o mito da invenção das flautas de Atena era narrado na décima segunda ode pítica.

Em minha opinião, todos esses elementos nos encorajam fortemente a pensar que todo o programa era concebido como uma celebração da poesia. Na verdade, as alusões à música são numerosas: o epigrama N3 alude ao certame musical de Mársias; na pintura N7, a máscara de Polifemo jaz perto de uma lira ${ }^{31}$; em N6, a carruagem puxada por grifos contém a "lira melodiosa" de Apolo, à qual alude o epigrama (

Muitos detalhes podem sugerir uma discussão sobre a linguagem poética: as máscaras de Polifemo e Galatéia, os pássaros e a cigarra da área de recesso, as flores (Narciso, as violetas de Íamo, bem como as flores pintadas nos afrescos), Hércules tecendo e trabalhando a lã, poderiam ser interpretados como símbolos de poesia: Outro exemplo possível seria a alusão a кoũ significativo de um ponto de vista metaliterário, se pensamos na importância de imagens de crianças e jovens no modo como autores como Calímaco definem sua própria identidade poética ${ }^{32}$.

\footnotetext{
${ }^{28}$ Veja-se Scrinari/Morricone Matini, 1975, 73.

${ }^{29}$ Cf. Pompéia, ins. 8.4.34 (tablinum 4).

${ }^{30}$ Prop. 4.9.47-50; Ov. Her. 9.75-80.

${ }^{31}$ Polifemo aparecia como um tocador de cítara no Ciclope de Filóxeno: cf. Ar. Pl. 290-295 com $\Sigma 290$ c; PMG 819 . Esse traço raro também aparece em uma pintura pompeiana (Nápoles, $M N N$, inv. nr. 8984): cf. Touchefeu-Meynier LIMC VIII/1 (supplementum), (1997), cat. nr. 64)

${ }^{32}$ Veja-se, por exemplo, Ambühl, 2005. 
Se tentamos analisar coerência temática da parede norte, um dos pontos mais marcantes acaba sendo a presença recorrente de rebanhos e pastores: na ponta esquerda da série, vemos Polifemo e Galatéia, ambos pastoreando diferentes tipo de rebanho (o $\pi o i ́ \mu v \eta$ de Polifemo é composto de ovelhas e cabras, ao passo que o de Galatéia é composto de golfinhos). A vinheta central nos apresenta cabras, e o epigrama na ponta direta da série nos apresenta um $\pi$ oú $\nu \eta \eta v$, um rebanho. Há um efeito de composição anelar formado por essas três vinhetas cujo ponto comum está na sua alusão a rebanhos e pastores. Essas alusões a rebanhos, poesia e certame musical nos leva a pensar que pelo menos algumas das pinturas e dos epigramas da parede norte eram concebidos como uma celebração da poesia pastoral.

Vale a pena notar que, em seu décimo primeiro idílio, Teócrito representou Polifemo como um tipo de poeta doctus ${ }^{33}$. Nesse poema, que dirigido ao amigo de Teócrito, Nícias, um poeta e médico siciliano, vemos um Ciclope siciliano compondo canções pastorais para curas suas próprias dores de amor.

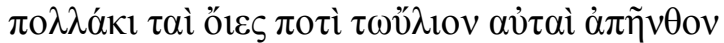

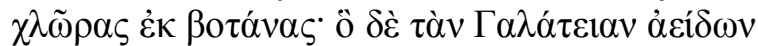

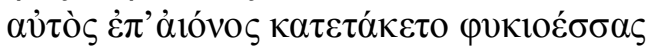

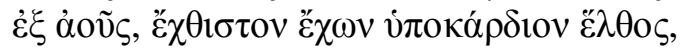

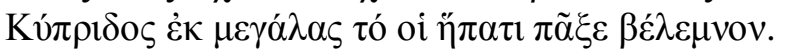

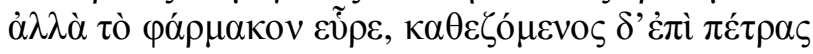

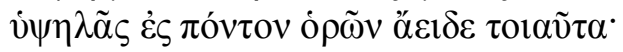

$$
\begin{aligned}
& \text { Muitas vezes suas ovelhas vieram por si mesmas, para sua cabana, } \\
& \text { dos verdes pastos, enquanto ele, cantando Galatéia, } \\
& \text { definhava sobre a costa cheia de algas, } \\
& \text { desde a aurora, tendo no fundo do seu peito um odioso ferimento } \\
& \text { que a flecha da deusa cípria ficou no seu coração. } \\
& \text { Mas ele encontrou o remédio e, sentado sobre rocha } \\
& \text { alta, olharia para o mar e catanva assim:... }
\end{aligned}
$$

O poeta que compôs os epigramas de Assis certamente tinha plena ciência da imagem de Polifemo como um poeta. Na verdade, $\mathrm{Eu}$ defenderia que esse poeta anônimo retrabalhou tanto um dístico de Teócrito quanto uma linha de Bíon para compor seu próprio epigrama. A estrutura do epigrama encontrado em Assis apresente uma forte semelhança com um dístico tirado do sexto idílio:

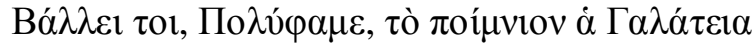

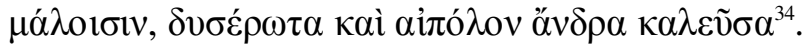

$$
\begin{aligned}
& \text { Polifemo, Galatéia repele teu rebanho } \\
& \text { com maçãs e te chama amaldiçoado no amor e cabreiro. }
\end{aligned}
$$

Os nomes dos personagens ocupam as mesmas posições na primeira linha. Ambos os dísticos começam com um verbo na terceira pessoa e são completados por uma estrutura participial. Se a estrutura sintática do epigrama de Assis parece ser inspirada pelo sexto idílio de Teócrito, seu vocabulário possivelmente deriva de Bíon

\footnotetext{
${ }^{33}$ Cf. Mazur, 2003. Veja-se também Calim.. Ep. 46 Pf.

${ }^{34}$ Teocr. 6.6-7.
} 


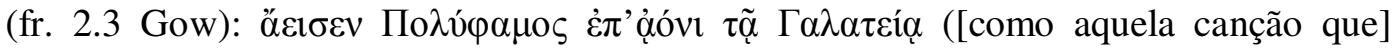
Polimefo cantava na praia para Galatéia) ${ }^{35}$.

Polifemo não é o único poeta ou músico mostrado na parede norte: as pinturas e epigramas aludem também a Apolo, a Mársias e talvez a Orfeu. Também deveríamos notar a importância que é dada à adivinhação e às imagens de vates e profetas: o epigrama N2 alude aos cท́ $\mu \alpha \tau \alpha \mu \alpha v \tau o c u ́ v \eta c$ (símbolos de adivinhação). O caso de Íamo, um famoso vate e o fundador do oráculo de Olímpia ${ }^{36}$, é peculiarmente impressionante. O programa pictorial de Assis pode, com efeito, ter derivado das semelhanças entre a estória de Íamo e a própria biografia de Píndaro, tal como reconstruída pelos eruditos antigos: diz-se que Píndaro foi abandonado quando era um bebê e que sobreviveu graças às abelhas que depositavam meu nos seus lábios ${ }^{37}$. Esse vaticínio provavelmente foi inspirado em imagens das artes visuais: Filostrato nos dá uma extensa descrição de uma pintura que retrata esse episódio ${ }^{38}$. O bebê Íamo haveria de tornar-se um famoso vate, mas ele também podia ser percebido como uma imagem de poeta quando jovem.

De modo semelhante, o mito de Narciso estava, de modo insigne, aos vaticínios do profeta Tirésias: na versão de Ovídio, o vate anunciava à mãe de Narciso que o garoto viveria muito, "se jamais conhecesse a si mesmo"39. Quanto à estória de Polifemo, ela estava notavelmente ligada à predição de Têlemo, que visitou o Ciclope quando este estava apaixonado por Galatéia e que predisse que ele perderia seu olho ${ }^{40}$. $\mathrm{Na}$ Odisséia, o Ciclope relembra a predição do vate depois de ter sido cegado, exatamente no momento em que começa a arremessar rochas na nau de Odisseu ${ }^{41}$. Se as imagens do corredor representavam os dois episódios da vida do Ciclope, a ligação entre as duas vinhetas teria sido a predição de Têlemo e a famosa comparação que Teócrito e Ovídio fizeram entre Polifemo metaforicamente cegado pelo amor de Galatéia e Polifemo fisicamente cegado por Odisseu ${ }^{42}$. Ambos os episódios se também se conectavam nas artes visuais, como pode ser visto no afresco encontrado na Villa Imperiale em Boscotrecase ${ }^{43}$.

Assim, parece que as pinturas da asa leste jogavam com alusões a poetas e profetas, cuja equivalência é tornada clara na palavra latina vates. Se a parede note é dedicada à poesia pastoral, a parede sul poderia ser dedicada a poemas de amor e, talvez, à elegia erótica: a ligação entre o mito de Narciso e o mito de Hércules servindo Ônfale pode depender da sua alusão comum às transformações causadas pelo amor. Hércules e Narciso foram ambos enfraquecidos por sua paixão: um deles vestia roupas femininas e o outro desapareceu, perdido na contemplação da sua própria imagem. A servidão de Hércules pode ser interpretada como uma alegoria da seruitium amoris do amante elegíaco $^{44}$, ao passo que o lânguido desejo de Narciso ilustra o amor impossível. Mas Hércules e Narciso não são apenas símbolos do destino sofrido pelo amante

\footnotetext{
${ }^{35}$ Desejo agradecer Marco Fantuzzi por este paralelo.

${ }^{36}$ Cf. Pind. O. 6.51-52

${ }^{37}$ Cf., por exemplo, Antip. Thess. GPh 487-92 = APl 305; Barbantani, 1993, 22-23.

${ }^{38}$ Filost. Im. 2.12. Cf. também Cristod. AP 2.382-387.

${ }^{39}$ Cf. Ov. M. 3.348 .

${ }^{40}$ Cf., por exemplo, Ov. M. 13.770-775: Telemus interea Siculam delatus ad Aetnen,/ Telemus Eurymides, quem nulla fefellerat ales,/ Terribilem Polyphemon adit 'lumenque quod unum / Fronte geris media, rapiet tibi' dixit 'Ulixes.' / Risit et: 'O uatum stolidissime, falleris;' inquit / 'Altera iam rapuit'”. (“Enquanto isso, Têlemo viera ao Etna siciliano, Têlemo, filho de Êurimo, a quem nenhum pássaro enganara; e ele disse ao terrível Polifemo: 'esse único olho que tens no meio da testa, Ulisses o tirará de ti'. Ele riu e respondeu: 'Ó vate estultíssimo, estás errado; uma outra já o tomou'”.

${ }^{41}$ Od. $9.508-512$.

${ }^{42}$ Teocr. 6.22-24; Ov. M. 13.770-775.

${ }^{43}$ New York, MET, Rogers Fund, inv. no. 20.192.17. Cf. Blanckenhagen/Alexander/Papadopulos, 1962.

${ }^{44}$ Prop. 3.11.17-20; Ov. Ars Am. 2.217-222. Cf. Copley, 1947. 
elegíaco: eles também podem representar o próprio ato de escrever poesia. Como dissemos, a tecedura de Hércules pode aludir à famosa comparação entre tecer e escrever poesia. Quanto a Narciso, G. Rosati mostrou que ele era uma das figuras chave do discurso metapóetico de Ovídio: o Narciso de Ovídio pode ser interpretado como uma imagem do poeta trabalhando ${ }^{45}$. Pode-se pensar que a suavidade (mollitia,

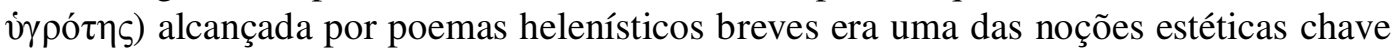
promovidas em contextos programáticos, em oposição à "dureza" às vezes relacionada com o genus grande.

Uma outra pista das ligações entre as imagens da parede sul e a poesia elegíaca pode ser encontrada na pintura S10: o infortúnio de Tereu. Essa imagem estava necessariamente ligada a Filomela, o rouxinol. Na poesia grega, o rouxinol era tradicionalmente usado como uma imagem do cantor ou do poeta ${ }^{46}$, mas a poesia augustana fornece exemplos consistentes de uma associação específica entre o lamento de Filomela e a poesia elegíaca ${ }^{47}$. Com efeito, P Monella recentemente estudou o modo como tanto Propércio quanto Ovídio introduziram o rouxinol nos elementos tópicos do panorama elegíaco ${ }^{48}$.

Em minha opinião, todos esses elementos mostram convincentemente que as pinturas do corredor foram concebidas como uma celebração da poesia: a parede norte provavelmente aludia à poesia bucólica, enquanto as duas imagens sobreviventes da parede sul possivelmente foram planejadas para evocar a poesia erótica e, mais especificamente, a elegia. Além disso, parece que o programa pictórico da asa leste era de fato baseado em efeitos múltiplos de intertextualidade. É tentador notar a semelhança entre o epigrama sobre Narciso e as palavras de Narciso no terceiro livro das

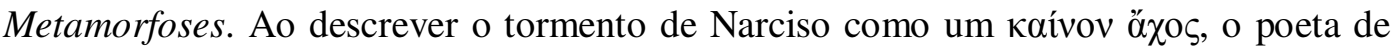
Assis empregou uma expressão notavelmente próxima do nouitas furoris de Ovídio ${ }^{49}$.

Também deveríamos notar que Polifemo era representado como um novo e monstruoso Narciso por Teócrito e $\mathrm{Ovídio}^{50}$. O Ciclope de Teócrito temia ser enfeitiçado por sua própria beleza:

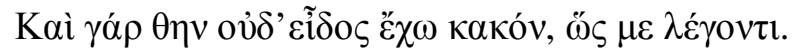

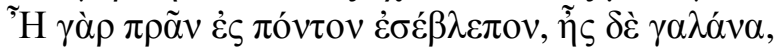

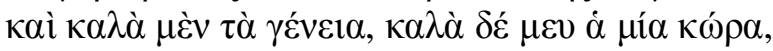

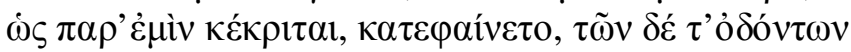

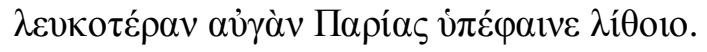

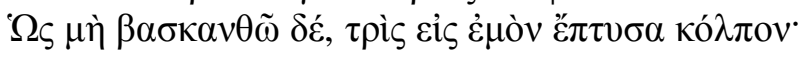

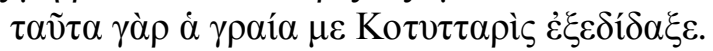

Pois verdadeiramente não sou desajeitado, como dizem; pois recentemente olhei para o mar, que estava calmo, e bela mostrou-se minha barba e meu único olho, como é meu juízo, e dos meus dentes refletiu o brilho mais branco do que o mármore pariano. Mas, para enganar o olho invejoso, três vezes cuspi no meu peito, como me ensinou a velha Cotitáris.

\footnotetext{
${ }^{45}$ Ov. M. 3.339-510. Cf. Rosati, 1976 e 1983; Kilgour, 2005; Prioux, 2008 (a).

${ }^{46}$ Cf. Monella, 2005, 221-251.

${ }^{47}$ Veja-se, por exemplo, V. G. $4.507-520$.

${ }^{48}$ Monella, 2005, 242-251. Cf. Prop. 1.18.25-32; Ov. Am. 3.1.1-8; Her. 15.153-156.

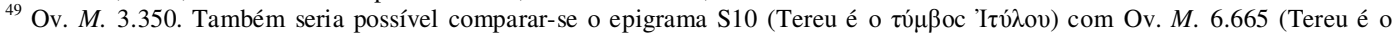
bustum miserabile nati).

${ }^{50}$ Cf. Teocr. 6.34-40; Ov. M. 13.840-841.
} 
O Polifemo de Ovídio diz:

Certe ego me noui liquidaeque in imagine uidi nuper aquae, placuitque mihi mea forma uidenti.

Certamente conheço a mim mesmo; recentemente vi meu reflexo em uma poça límpida, e minha forma me agradou, quando a vi.

As palavras de Polifemo (certe ego me noui) claramente ecoam a predição de Tirésias sobre Narciso: o garoto viverá muito si se non nouerit ${ }^{51}$. Representações poéticas de Polifemo e Narciso eram intimamente relacionadas e ambos os personagens tinham um papel importante na auto-definição da poesia bucólica e da elegia. Um outro exemplo se baseia nas alusões intertextuais do relato de Ovídio do mito de Narciso. Quando o Narciso de Ovídio exclama iste ego sum! sensi; nec me mea fallit imago (M. 3.463), o leitor se lembra do Córidon de Vergílio, que, falando de seu reflexo na água, diz: si numquam fallit imago (E. 2.27). É interessante que o Córidon de Vergílio estava, por sua vez, citando o Polifemo de Teócrito: nec sum adeo informis: nuper me in litore vidi (E. 2.25) /

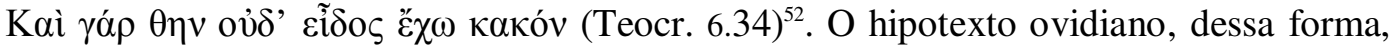
conecta fortemente Polifemo e Narciso.

No ciclo pictório de Assis, a relação que ligava Polifemo e Narciso, que iram ambos contemplar amorosamente a água, pode explicar a posição das pinturas S5 e N7. Ambas as imagens, com efeito, estavam intimamente associadas no ciclo pictório de Assis.

Assim, o estudo das pinturas nos leva a uma conclusão paradoxal: eu argumentei que o ciclo pictório foi concebido e completado muito depois da morte de Propércio, mas, por outro lado, esse programa decorativo foi profundamente influenciado por textos poéticos e provavelmente esconde alusões metapoéticas. Se dermos um passo além, podemos tentar mostrar que os epigramas e pinturas da asa leste foram concebidos como uma homenagem à poesia de Propércio. Algumas das chaves para o sentido das imagens dispostas nesse corredor podem, com certeza, ser procurados nas Elegias de Propércio.

Diferentemente dos pintores, os poetas tradicionalmente não representam Galatéia como uma ninfa montando na direção de Polifemo ${ }^{53}$. Galatéia era, antes, mostrada como fugindo do Ciclope. No entanto, uma exceção é encontrada precisamente na poesia de Propércio: na Elegia 2. 2, Polifemo é representado como um cantor que tinha a habilidade de encantar Galatéia e de atraí-la até a costa.

\footnotetext{
Orphea delenisse feras et concita dicunt flumina Threicia sustinuisse lyra; saxa Cithaeronis Thebanam agitata per artem sponte sua in muri membra coisse ferunt; quin etiam, Polypheme, fera Galatea sub Aetna ad tua rorantis carmina flexit equos: miremur, nobis et Baccho et Apolline dextro,
}

\footnotetext{
${ }^{51}$ Ov. M. 3.348; para um paralelo entre as duas passagens, veja-se Bömer, 1982, 437. Para outras reflexões acerca dessa frase, vejase Kilgour, 2005.

${ }^{52}$ Cf. Fabre-Serris, 1998, que interpreta essas passagens como alusões às elegias de Galo: nessa visão, o interesse no belo corpo visto na superfície da água poderia ter sido um motivo galiano.

${ }^{53}$ Para imagens de Galatéia apaixonada por Polifemo, cf. Touchefeu-Meynier, LIMC VIII/1 (supplementum) (1997), nrs. 59, 63, 64. 


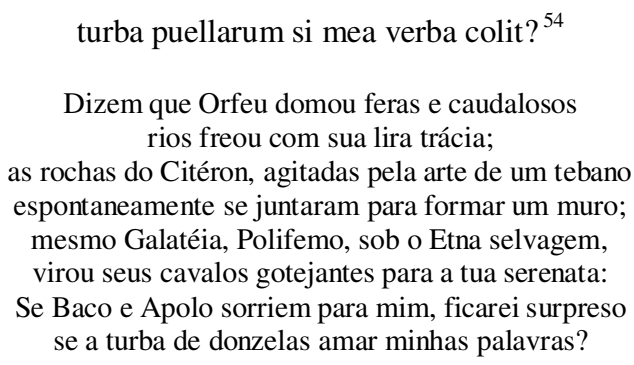

O poema celebra o poder da canção, o mesmo tema que sugeri estar representado no ciclo pictório de Assis. É interessante notar que Propércio traça uma comparação entre Polifemo encantando Galatéia, Orfeu domando feras, e o poeta seduzindo uma turba de donzelas com a ajuda de Baco e Apolo: como vimos, o amor de Polifemo por Galatéia era, com efeito, juntamente do poder de Baco e de Apolo, entre os temas principais do ciclo de Assis, e Orfeu possivelmente era representado em uma das pinturas perdidas.

Outro paralelo tentador entre a coleção de epigramas encontrados no criptopórtico e a poesia de Propércio pode ser encontrado no epigrama N3 (a flauta de Mársias). Esse epigrama, com efeito, é concebido como um tipo de enigma geográfico: é dito que as flautas foram abandonadas na lago Tritônis e, então, encontradas por um Frígio. Uma suposta dificuldade emerge da locação do lago Tritônis na Líbia, não na Frigia. A única solução para esse problema geográfico é considerar que o autor dos epigramas de Assis pensava que a flauta flutuara milagrosamente do norte da África até a costa da Frigia, onde foi encontrada por Mársias. Como notado por Giangrande (1997), essa hipótese encontra suporte na crença antiga de que o lago Tritônis se

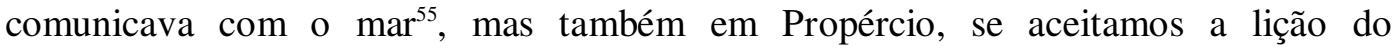
manuscrito:

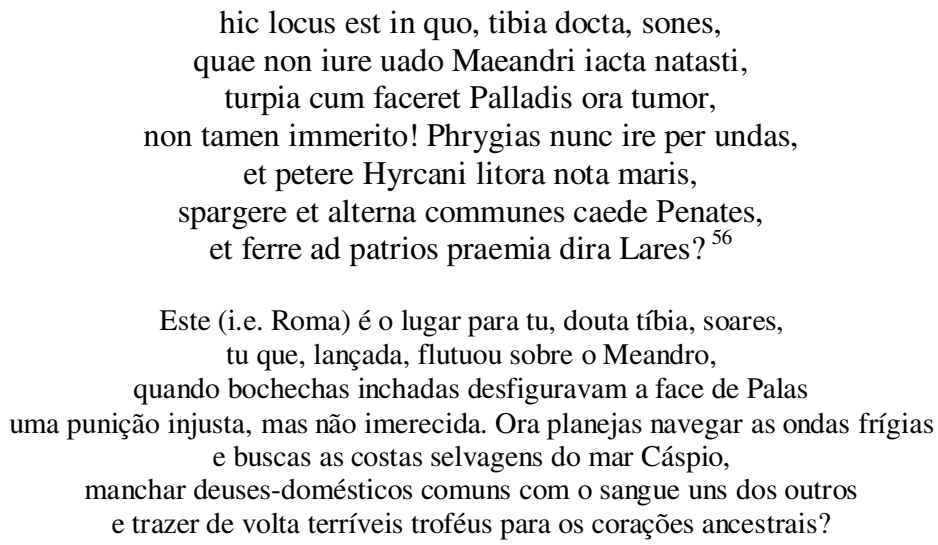

Nesse poema, a flauta é apresentada com duas direções possíveis para sua navegação: ela poderia tanto deixar a Frigia e ir a Roma, quanto continuar seu caminho para o leste e alcançar regiões inóspitas. A idéia subjacente, sem dúvida, é a de que a

\footnotetext{
${ }^{54}$ Prop. 2.2.3-10.

${ }^{55}$ Líc. 886-890; Apol. Rod. 4.1579; Delage 1930, 263-264.

${ }^{56}$ Prop. 2.30.16-22. O texto apresentado aqui corresponde à versão transmitida pelos manuscritos; edições recentes reformularam a passagem inteira e a consideram um locus desperatus; cf. Giangrande, 1997.
} 
flauta de Mársias deveria chegar a Roma, que é apresentada como um lugar que acolhe a poesia e a música. Essa elegia propérciana, dessa forma, dá suporte à idéia de que a flauta de Mársias realizara uma navegação milagrosa - uma idéia também suportada, como acabamos de ver, pelas alusões geográficas contidas no epigrama de Assis. Portanto, é razoável que nós devamos reconhecer várias alusões à poesia de Propércio na coleção de imagens que fora concebida por um de seus conterrâneos.

Alusões poéticas e metapoéticas, assim, estão presentes por todo o conjunto de representações artísticas que sobreviveram na Casa de Propércio. A coleção de poemas e a coleção de pinturas foram ambas concebidas para celebrar uma série de poetas: Homero, Píndaro, Teócrito, mas também Ovídio e Propércio. O arranjo habilidoso das duas coleções poderia nos lembrar da ênfase que Meleagro punha na arte de editar epigramas na sua própria antologia. Se aceitamos essa hipótese, o belo trilho de flores e ramos floridos que adornam a parte central do corredor também poderiam ser interpretados como uma inteligente alusão a outra metáfora metapoética: poderíamos, certamente, pensar em Meleagro entrelaçando sua Guirlanda de poemas a fim de compor uma antologia ${ }^{57}$.

\section{QUANDO UM POETA ANÔNIMO SE ENGAJA NUM DEBATE SOBRE BUCÓLICA E ELEGIA}

Com as principais alusões textuais reconhecidas, é possível propor uma análise abrangente de seu significado. Tentou o autor dos epigramas expressar, através de textos e imagens, um discurso metapoético coerente? Estava ele reagindo a debates literários conhecidos, por exemplo, na literatura grega ou na latina? Aceita leitura metapoética do ciclo, é possível especificar seu significado?

Como notamos nos parágrafos precedentes, os epigramas e as pinturas chave da parede norte $(\mathrm{N} 1, \mathrm{~N} 4, \mathrm{~N} 7)$ parecem aludir à poesia pastoral, enquanto as três pinturas restantes da parede sul envolvem imagens associadas às elegias de amor. As alusões à poesia pastoral são indicadas por uma série de alusões a rebanhos e pastores: o Ciclope, por exemplo, serviu como um modelo para a pré-história da poesia bucólica desde que Teócrito compôs os Idílios 6 e 11. De maneira significante, o tom pastoral dos epigramas da parede norte coexiste com numerosas alusões ao estilo grandioso. Essas alusões são reveladas pela presença surpreendente de uma lira próxima a Polifemo na pintura N7 (a tradicional flauta do Ciclope foi substituída por uma lira), pela $\varphi o ́ \rho \mu \imath \gamma \xi$ de Apolo na pintura e no epigrama N6, pela referência indireta à poesia lírica de Píndaro na pintura e no epigrama N5, e, sobretudo, pela vitória da lira de Apolo sobre as flautas de Mársias no epigrama N3. Nesse sentido, é interessante notar que o epigrama N3, assim como o epigrama N7, estava possivelmente preocupado com a arqueologia da poesia pastoral por fornecer uma etiologia da invenção das flautas e, talvez, pela

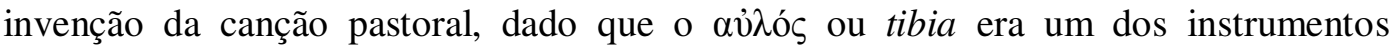
comumente associados à poesia bucólica ${ }^{58}$. Se for assim, a competição entre Apolo e Mársias poderia indicar a ameaça que outros gêneros e temas mais pomposos representavam para a poesia pastoral: as flautas de Mársias rendiam-se à lira nãobucólica de Apolo. Uma leitura similar da competição entre Pan e Apolo nas Metamorfoses (11.146-192) foi proposta por A Barchesi em um artigo recente que tinha como foco a representação ovidiana da canção bucólica no interior do plano de seu

${ }^{57}$ Cf. $A P 4.1$ e Gutzwiller, 1998

${ }^{58}$ Cf. Smith, 1970,501 e n. 16. 
próprio poema épico ${ }^{59}$ : nessa passagem, a flauta bucólica de Pan se rende à lira de Apolo. Embora a sirinx ( $\sigma \tilde{\rho} \rho \imath \xi \xi /$ fistula) de Pan seja mais propícia a ser lida como um símbolo pastoral do que as flautas de Mársias, as alusões metapoéticas de Ovídio à história da poesia pastoral parecem fornecer um paralelo para a imagem de Assis. Essa leitura pode encontrar apoio na arquitetura do ciclo pictório: se nos lembrarmos que N5 e N3 berloques, é provável que ambas as imagens servissem para transmitir idéias similares ou, pelo menos, comparáveis. É interessante que a poesia de Píndaro era vista

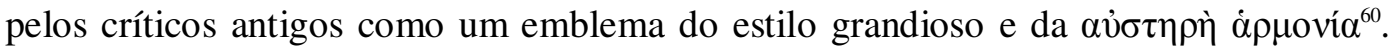
Além disso, um epigrama de Antípatro afirmava que a lira de Píndaro pairava muito acima de todos os outros instrumentos: o próprio Pan "esqueceu sua flauta" para cantar um dos hinos do poeta ${ }^{61}$. Eu, portanto, sugeriria que o poeta de Assis preocupava-se com a relação ambígua entre a poesia pastoral e o estilo grandioso, entre o gênero bucólico e gêneros poéticos mais elevados.

Se correta, a análise de N4 como uma alusão a Polifemo arremessando rochas apoiaria a idéia de que as imagens nessa parede tratavam de uma possível redefinição da pastoral em termos mais pomposos. A evidência literária, com efeito, mostra que havia, em algum momento, um debate estético entre os críticos antigos acerca das várias frases que poetas poderiam usar para descrever o gesto de Polifemo nesse episódio específico $^{62}$. No tratado Sobre o Estilo, pseudo-Demétrio menciona o estilo frio

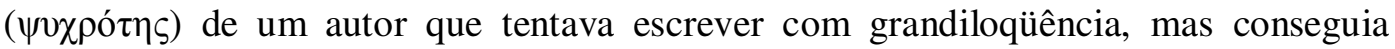
apenas compor um exagero sem sentido ao dizer que "quando a pedra foi lançada pelo

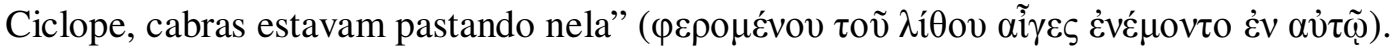
Sêneca, o Velho, zomba da turgidez da paráfrase de Dórion a Homero, exatamente na mesma passagem em que o Ciclope cegado lança uma rocha ao mar, e acrescenta que "Mecenas costuma dizer que Vergílio permitia que se entendesse como uma passagem assim, em vez de ser decadente, poderia ser tornada grandiosa e sensata ao mesmo tempo. É bombástico dizer: 'Montanha é arrancada de montanha'. Então, que diz Vergílio? 'Ele agarra uma parte não pequena da montanha'. Ele mantém o tamanho em mente e, assim, evita descartar a verdade descuidadamente" ${ }^{63}$. Em sua recente discussão acerca da percepção da pastoral nas Metamorfoses, A. Barchiesi (2006) mostrou que o relato de Galatéia de Polifemo esmagando Ácis com uma rocha fornecia um bom indício de que Ovídio se engajava de modo divertido no mesmo debate e refletia, de fato, acerca do problema da auxesis na poesia bucólica ${ }^{64}$ : era possível fazer a poesia pastoral elevar-se além dos seus limites tradicionais? Como notou Barchiesi, o final da passagem ovidiana deveria ser lida como uma alegoria metapoética: a rocha que esmagou o corpo de Ácis é um moles, uma massa na costa marítima (13.887 e 890), mas Ácis finalmente reaparece como um magnífico deus fluvial elevando-se de abaixo desse moles. Uma vez que pedras, seixos e rios são metáforas para poesia, toda a passagem provavelmente tem a ver com a auxesis na poesia pastoral e a possibilidade de magnificar esse gênero literário. A escolha de um personagem como Polifemo, um Ciclope cujo nome significa "muito falado", mas também "de muitas vozes",

\footnotetext{
${ }^{59}$ Cf. Barchiesi, 2006.

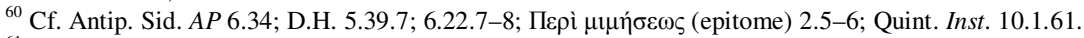

${ }^{61}$ APl 305. Cf. Barchiesi, 2006.

${ }^{62}$ Cf. [Demetr.]. 2.119; Sen. Suas. 1.12; Petrain, 2003, 383-384.

${ }^{63}$ Sen. Suas. 1.12: "Haec quo modo ex corruptis eo perueniant ut et magna et tamen sana sint aiebat Maecenas apud Vergilium

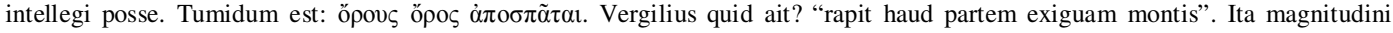
studet $<$ ut $>$ non inprudenter discedat a fide".

${ }^{64}$ Ov. M. 13.750-898 e esp. 13.883, com Barchiesi 2006.
} 
"polifônico", "de muitas palavras" ${ }^{65}$, pode ser peculiarmente significativa no pano de fundo desse debate literário.

A idéia de que o gesto de Polifemo e sua descrição tinham um significado específico na crítica literária também pode ser procurada em textos anteriores. Eu defenderia que uma reflexão semelhante sobre o $\mu \varepsilon \gamma \varepsilon \dot{\varepsilon} \theta$ o $\varsigma$ na poesia estava presente nos lithika de Posidipo e nos epigramas 19A-B. Esse epigrama contém uma referência intertextual aos idílio de Teócrito e compara um enorme rochedo arremessado à beiramar pela mão de Posêidon até a rocha que selou a caverna de Polifemo ${ }^{66}$. Nesse poema, Posidipo combina uma alusão a Teócrito, o pai da poesia bucólica, e a Homero, o pai da poesia épica: através dessa dupla referência, Posidipo talvez refletisse acerca da relação entre épica e bucólica. Na verdade, a idéia de que esse epigrama se referisse metaforicamente à criação poética encontra apoio no uso que o poeta faz de uma série de palavras que tinham, certamente, um significado específico na crítica literária antiga:

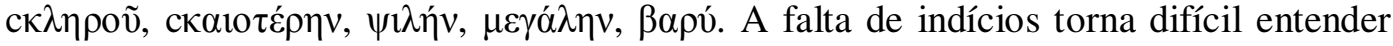
claramente o significado que os poetas helenísticos davam ao gesto de jogar uma pedra, mas é provável que a imegem de Polifemo arremessando rochas contra a nau de Odisseu tenha se tornado parte de uma reflexão acerca do estilo poético muito cedo. Se nossa leitura do painel N4 está correta, o poeta de Assis estava engajado num grande debate sobre poesia bucólica, cujas raízes provavelmente devem ser procuradas no ínicio da crítica helenística.

Se a parede norte trata de uma possível redefinição da pastoral em termos mais pomposos, um raciocínio semelhante pode ser aplicado à elegia na parede sul. Um paralelo convincente para essa análise da pintura S3 (Hércules e Ônfale) pode ser encontrado em uma das Elegias de Propércio. Como foi mostrado por J. DeBrohun, o travestimesnto de Hércules na Elegia 4. 9 parece ser uma imagem programática concebida para simbolizar a poética do último livro de Propércio. O quarto livro das Elegias supostamente oscila entre dois temas principais: amor e Roma. Exatamente essa oscilação está inscrita na Elegia 4. 1: após relatar as origens de Roma e engajar-se no verso patriota (1-70), o poeta é advertido por Horos de que sua sorte consiste em escrever elegias de amor ${ }^{67}$. Na Elegia 4. 9, Propércio aparentemente retorna ao seu projeto de escrever elegias etiológicas sobre a arqueologia romana. O poema explica porque mulheres não podiam participar do culto a Hércules na Ara Maxima: as mulheres que celebravam os ritos da Bona Dea certa vez recusaram-se a dar água a Hércules. Antes de voltar-se para a violência ao atacar o templo da Bona Dea e estabelecer um culto do qual mulheres eram excluídas, Hércules tentou convencer a sacerdotisa da Bone Dea a deixá-lo entrar no santuário narrando seus próprios feitos heróicos, mas também contando que fora, certa vez, uma apta puella na corte da Rainha Ônfale. Como notamos acima, a escravidão de Hércules pode ser interpretada como a própria imagem da seruitium amoris do amante elegíaco. A Elegia 4. 9, dessa forma, consiste de uma elegia de amor incorporada num poema etiológico e ilustra a tensão entre amor e Roma. Portanto, não apenas o travestimento de Hércules, o herói épico, e sua transformação em um exclusus amator aguardando do lado de fora do templo da Bona Dea, mas também sua transformação em puella, uma escrava e criada da Rainha Ônfale, poderiam ser lidos como um símbolo da poética do quarto livro de Propércio.

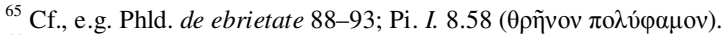

${ }^{66}$ Para uma leitura metapoética desse epigrama, veja-se, Petrain, 2003.

${ }^{67}$ Cf. Prop. 4.71-75: "quo ruis imprudens, uage, dicere fata, Properti? / non sunt a dextro condita fila colo. / accersis lacrimas cantans, auersus Apollo: / poscis ab inuita uerba pigenda Lyra”. 
De modo similar ao Verturmno da Elegia 4. 2, a escravidão de Hércules provavelmente deveria ser lida como uma alegoria metaliterária. Eu defenderia que o poeta anônimo de Assis de fato interpretava o poema de Propércio dessa maneira e que ele estava refletindo acerca das possibilidades da auxesis na poesia pastoral e elegíaca. Talvez devamos também comentar o paralelo que esse poeta anônimo traçou entre Hércules na Lídia, como uma possível imagem da elegia, e Mársias o frígio, como uma possível imagem da poesia pastoral. Em ambos os casos, a poesia corre o risco de ser praticada barbarico more.

Antes de concluir este artigo, eu gostaria de mencionar um dos sinais mais importantes do interesse do poeta anônimo em teoria literária e metapoética. Dois dos grafites apresentam correções ou leituras alternaticas que estão inscritas em baixo do texto. No caso do epigrama do epigrama S3, por exemplo, encontramos uma terceira

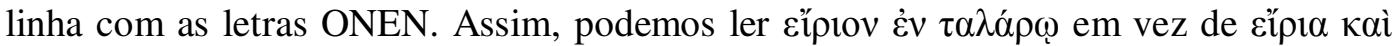

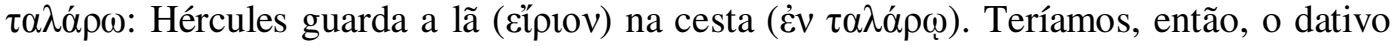
singular $\dot{\varepsilon} v \tau \alpha \lambda \alpha ́ \rho \omega$ (na cesta) em vez do acusativo do dual $\tau \alpha \lambda \alpha ́ \rho \omega$ (nas duas cestas).

Um interesse maior nas variantes textuais é claro no epigrama N7, que fornece três leituras possíveis:

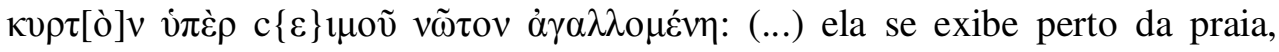
enquanto sentada no dorso curvado da besta de nariz arrebitado.

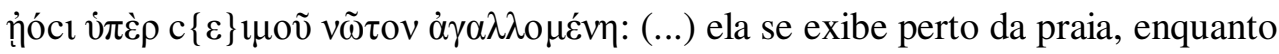
sentada no dorso da besta de nariz arrebitado.

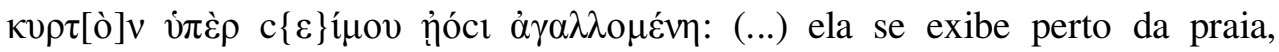
enquanto sentada na curva da besta de nariz arrebitado.

Com essas correções ou leituras alternativas, o poeta anônimo talvez tenha querido deliberadamente chamar a atenção do leitor para a $\sigma u ́ v \theta \varepsilon \sigma ı \varsigma$ (arranjo das

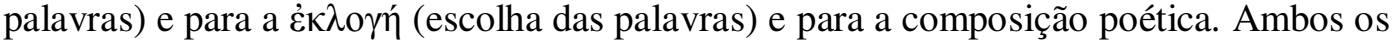
critérios estavam em jogo nas leituras alternativas do epigrama N7. Também deveria ser

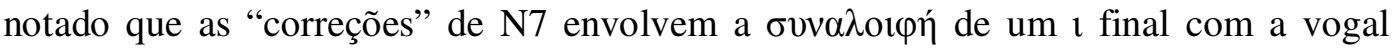
seguinte, um ponto delicado da métrica grega, uma vez que é menos freqüente com o 1 do que com outras vogais ${ }^{68}$. Ao juntar leituras alternativas aos seus grafites aparentemente escritos com descuido, o poeta anônimo de Assis pode ter tido a intenção de suscitar questões específicas concernentes ao estilo e à composição poética.

Para concluir este artigo, eu gostaria de insistir na considerável complexidade desse ciclo pictório. Sem dúvida, uma investigação baseada no significado possível dessas cenas mitológicas suscita um número de perguntas quase tão grande quanto as respostas que fornece, mas também nos possibilita vislumbrar o uso metafórico e metapoético de vários mitos. Embora um número considerável de incertezas permaneça, parece bastante claro que todo o ciclo foi concebido como uma celebração da poesia e como um meio de ilustrar idéias específicas acerca de gêneros literários e composição poética. Ironicamente, fomos continuamente guiados por textos propercianos enquanto analisávamos as pinturas que não foram encomendadas por Propércio e por epigramas que não foram escritos por Propércio. Deveríamos pensar que a cosidetta Casa di Properzio realmente era, afinal, a casa de Propércio e que ela foi redecorada no final do primeiro século ou no início do segundo por algum de seus parentes? O nome de Caio Passeno Paulo - um elegista, conterrâneo ou parente de Propércio ${ }^{69}$, e amigo de Plínio, o

\footnotetext{
${ }^{68}$ Veja-se Guilleux, 2001, 66-67.

${ }^{69}$ Veja-se Plin. Ep. 6.15, e possivelmente 9.22.
} 
Jovem, a quem Marcial possivelmente dirigiu vários epigramas - foi mencionado por vários estudiosos ${ }^{70}$. Se sua hipótese estiver correta, o testemunho de Plínio, o Jovem, na carta 9.22, seria o mais interessante, uma vez que ele celebra as habilidades que Passeno demonstrava tanto na elegia como um novo Propércio, quanto na poesia lírica como um novo Horácio: este último detalhe seria muito interessante em vista da clara referência a Píndaro na imagem $\mathrm{N} 5^{71}$.

\section{APÊEDICES}

\begin{tabular}{|c|c|c|c|}
\hline \multicolumn{2}{|r|}{$\begin{array}{c}\text { Epigramas inscritos na parede norte (procedendo } \\
\text { do Leste para o Oeste) }\end{array}$} & \multicolumn{2}{|l|}{$\begin{array}{c}\text { Epigramas inscritos na parede sul (procedendo do } \\
\text { Leste para o Oeste) }\end{array}$} \\
\hline N1 & 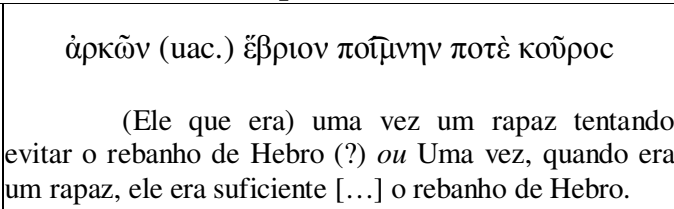 & lacuna (?) & S1 \\
\hline $\mathrm{N} 2$ & 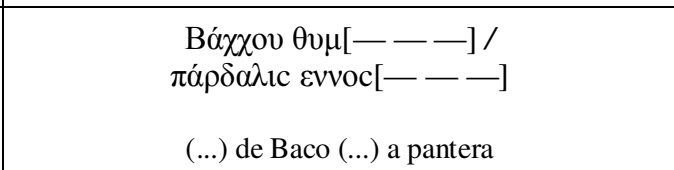 & pintura perdida & $\mathrm{S} 2$ \\
\hline $\mathrm{N} 3$ & 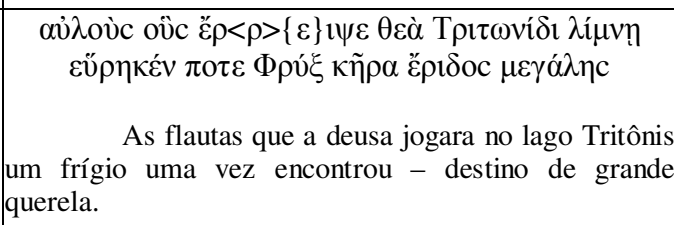 & 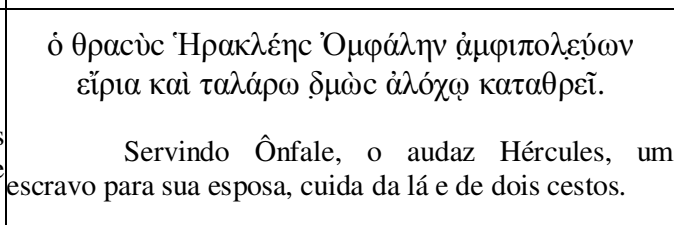 & $\mathrm{S} 3$ \\
\hline N4 & 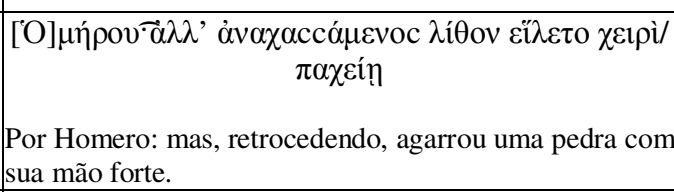 & janela & S4 \\
\hline N5 & 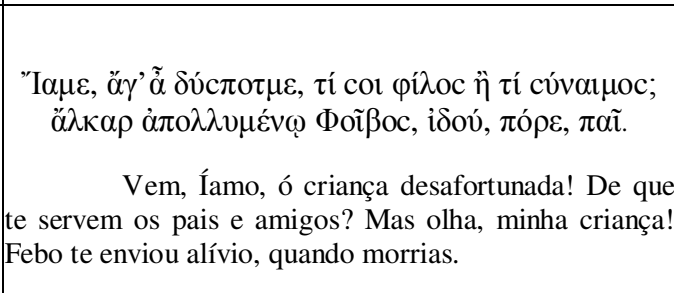 & 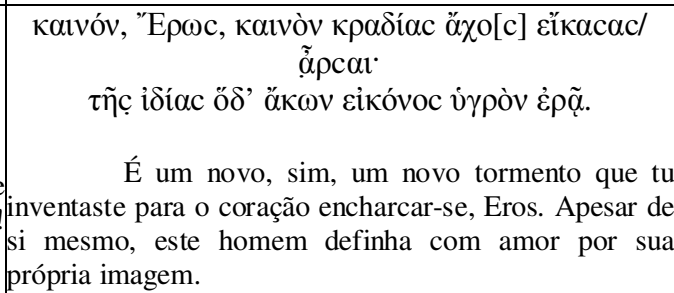 & S5 \\
\hline N6 & 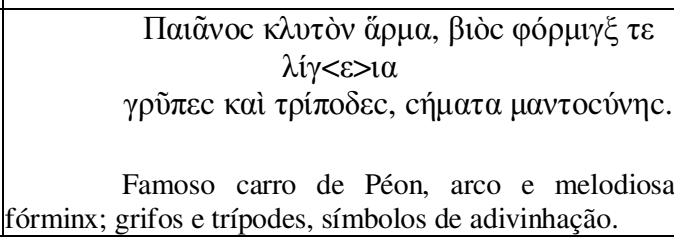 & pintura perdida & S6 \\
\hline
\end{tabular}

${ }^{70}$ Veja-se Guarducci, 1986a, 1986b, and 1986c; Coarelli, 2004, 106; Cairns, 2006, 29. De acordo com Plin. Ep. 9.22 (com uma leitura incerta), Passeno Paulo compôs um livro de poesia in Propertii domo scriptum or in Propertii modo scriptum. Sobre Passeno e Marcial, cf. Herrmann, 1975, que identifica o Paulus dos epigramas 2.20, 4.17, 5.22, 7.72, 10.10, e 12.69 com Passeno Paulo. ${ }^{71}$ Traduzido por José Baracat Jr. 


\begin{tabular}{|c|c|c|c|}
\hline N7 & 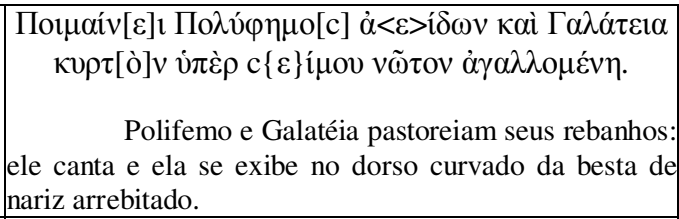 & lacuna (?) & S7 \\
\hline N8 & pintura leste da alcova & janela & S8 \\
\hline \multirow{2}{*}{$\begin{array}{c}\text { N9- } \\
10\end{array}$} & \multirow{2}{*}{ afrescos representando pássaros e flores } & pintura ilegível & S9 \\
\hline & & 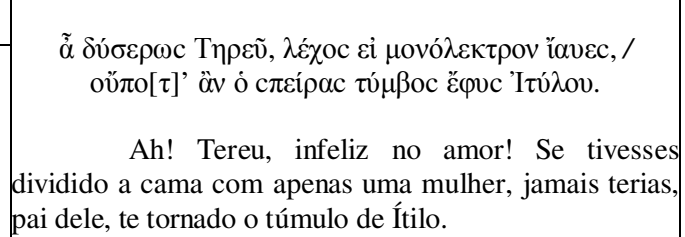 & S10 \\
\hline
\end{tabular}

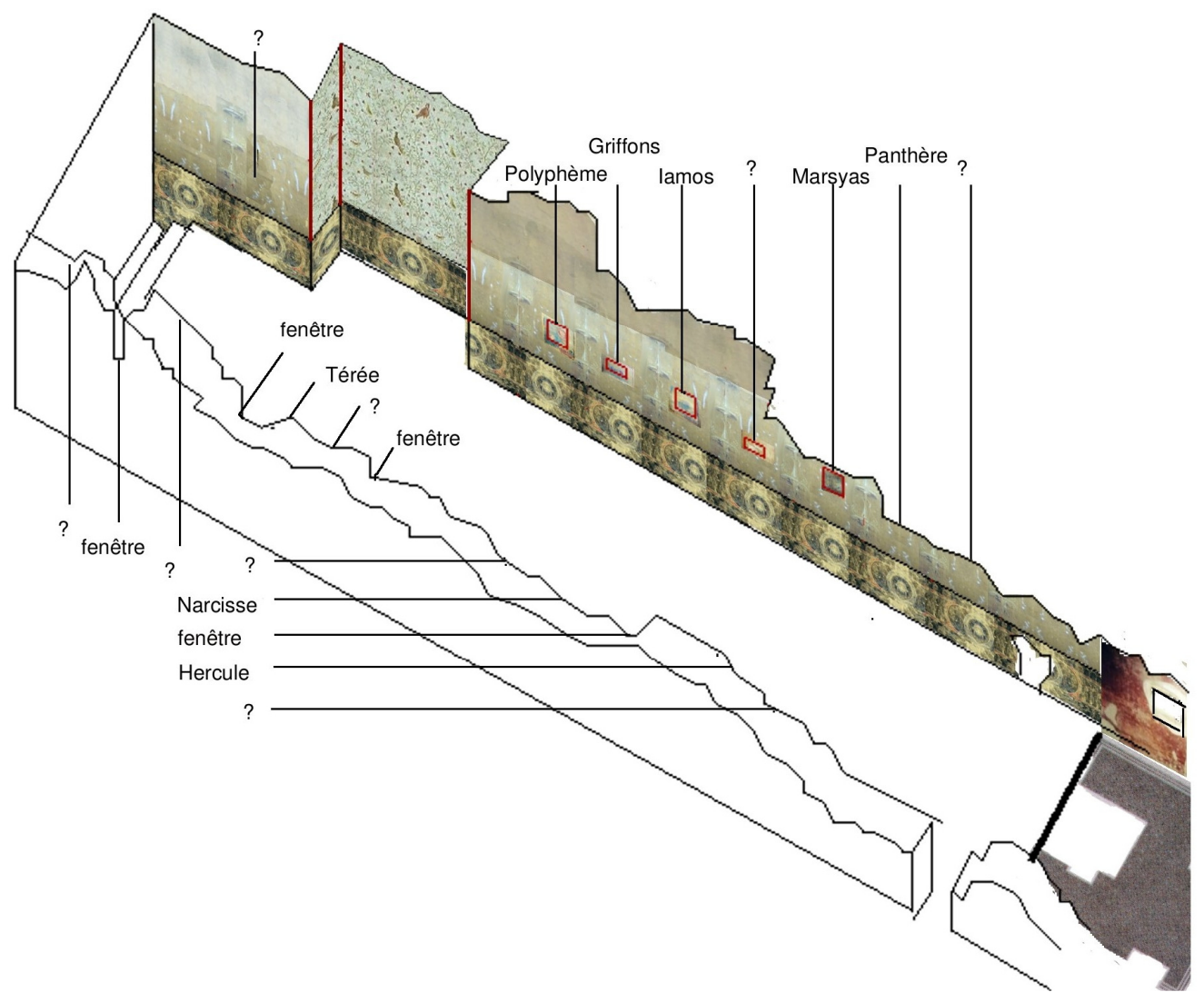

\section{BIBLIOGRAFIA}

AMBÜHL, A. Kinder und junge Helden, Innovative Aspekte des Umgangs mit der literarischen Tradition bei Kallimachos. Leuven: Peeters, 2005.

BARBANTANI, S. I poeti lirici del canone alessandrino nell' epigrammatistica. Aevum Antiquum, 6, pp. 5-97, 1993. 
BARCHIESE, A. Music for monsters: Ovid's Metamorphoses, bucolic evolution, and bucolic criticism. In: FANTUZZI, M. \& PAPANGHELIS, T. D. (orgs.), Brill's Companion to Greek and Latin Pastoral. Leiden: Brill, 2006.

BLANCKENHAGEN, P. H.; ALEXANDER, C.; PAPADOPULOS, C. The Paintings From Boscotrecase. F. H. Kerle Verlag, 1962.

BÖMER, F. P. Ovidius Naso: Metamorphosen, Kommentar. Buch VI-VII. Heidelberg, 1976.

Ovidius Naso: Metamorphosen, Kommentar. Buch XII-XIII. Heidelberg, 1982.

BULLOCH, A. Iamus and Narcissus in the "Domus Musae". Zeitschrift für Papyrologie und Epigraphik, 156, pp. 135-140, 2006.

CAIN, H. U. 1988. Chronologie, Ikonographie und Bedeutung der römischen Maskenreliefs. Bonner Jahrbücher, 188, pp. 107-221, 1988.

CAIRNS, F. Sextus Propertius: the Augustan Elegist. Cambridge: Cambridge University Press, 2006.

CIOTI, U.; PIETRANGELI, C. Assisi. EAA, 1, 741, Abb. 933, 1958.

COARELLI, F. Assisi, Roma, Tivoli. I luoghi di Properzio. In: SANTINI, C.; SANTUCI, F. (orgs.). Properzio tra storia arte mito. Atti del convegno internazionale. Assisi, 24-26 maggio 2002. Assisi, 2004.

COPLEY, F. O. (1947). Servitium Amoris in the Roman elegists. TAPhA, 78, pp. 285300, 1947.

CORALINI, A. Hercules domesticus. Immagini di Ercole nelle case della regione vesuviana (I sec. a. C. - 79 d. C.), «Studi della Soprintendenza archeologica di Pompei» (4), Naples., 2001.

DELAGE, E. La Géographie dans les Argonautiques d'Apollonios de Rhodes. Bordeaux: Feret et Fils, 1930.

DeBROHUM, J. B. Redressing Elegy's Puella: Propertius IV and the Rhetoric of Fashion. JRS, 84, pp. 41-63, 1994.

FABRE-SERRIS, J. Du «si numquam fallit imago» de la deuxième Bucolique au «sensi nec mea me fallit imago» du livre III des Métamorphoses: poétique et esthétique dans la conception ovidienne de l'image-reflet. In: AUVRAY-ASSAYAS, C. (orgs.). Images romaines: actes de la table ronde organisée à l'École normale supérieure (24-26 octobre 1996), Paris, 1998.

GALlAVOTTI, C. Domus Musae Asisinatis. Zeitschrift für Papyrologie und Epigraphik, 39, p. 278, 1980.

GIANGRANDE, G. A proposito della Domus Musae di Assisi. Studi di filosofia classica in onore di Giusto Monaco ( ${ }^{\text {rd }}$ vol.), Palermo, pp. 1275-1277, 1991. 1997.

The Carmina Asisinatia in the Light of Hellenistic Poetry. Myrtia, 12, pp. 9-24,

GUARDUCCI, M. Rassegna degli studi e delle scoperte di iscrizioni greche in Italia, Creta e Albania. Actes du deuxième congrès international d'épigraphie grecque et latine, Paris, pp. 47-58, 1953.

Epigrammi greci in una casa romana di Assisi. Atti del Colloquium Propertianum, pp. 123-129, 1977.

Domus Musae: epigrafi greche e latine in un' antica casa di Assisi. Memorie. Acc. Naz. Lincei, 269-297, 1979.

_. La casa di Properzio ad Assisi. Atti del Convegno Internazionale di Studi Properziani. Assisi, pp. 137-141, 1986 (a). 
La casa di Properzio: nuove riflessioni sulla Domus Musae di Assisi e sulle sue epigrafi. Acc. Naz. Lincei: Renconditi. 8, 40, pp. 163-181, 1986 (b).

Le epigrafi della Domus Musae ad Assisi e qualche osservazione nuova Zeitschrift für Papyrologie und Epigraphik, 63, pp. 161-167, 1986 (c).

GUIDOBALDI, F. Sectilia pavimenta d'Ostie. In: DESCOEDRES, J.-P. (org.). Ostia. Port et porte de la Rome antique (catalogue de l'exposition du musée Rath, Genève, 23 février-22 juillet 2001), pp. 361-364, 2001.

GUILLEUX, N. Le i bref de datif singulier athematique: les regles d'une elision homerique et tragique. $R P h, 75.1, \mathrm{pp} .65-82,2001$.

GUTZWILlER, K. J. Poetic Garlands-Hellenistic Epigrams in Context. Berkeley, Calif.: University of California Press, 1998.

HERRMANN, L. Martial, Epigrammes, XII, 47 (46). Latomus, 34, pp. 757-760, 1975.

KERÉNYI, K. Griechisches aus Properz' Heimat. Symbolar Osloenses, 29, 1, pp. 110 113, 1952.

KILGOUR, M. "Thy perfect image viewing": Poetic Creation and Ovid's Narcissus in Paradise Lost. Studies in Philology, 102.3, pp. 307-39, 2005.

LAURENS, P. L'abeille dans l' ambre. Paris, Les Belles-Lettres, 1989.

LAUSBERG, M. Das Einzeldistichon: Studien zum antiken Epigramm (Studia et testimonia antiqua, 19). Munich: Wilhelm Fink, 1982.

LEACH, E. W. Polyphemus in Landscape: Traditions of Pastoral Courtship. Studies in the history of art, 36, pp. 62-87, 1992.

MANCA, M. L.; SCALEGGI, A.; VERGONI, S. La casa romana "di Properzio" ad Assisi. Interventi di restauro e consolidamento, Soprintendenza per I Beni Archeologici dell'Umbria, s. 1, 2003.

MAZUR, P. Theocritus 11.56-9: Polyphemus as Hellenistic Poet? The Theocritus Colloquium, Center for Hellenic Studies, Harvard. [online] Disponível em: http://chs.harvard.edu/wb/5/wo/x6nyIJnIQinHbgGh2TSc90/0.1, maio de 2003.

MEDAGLIA, S. M. Per il testo degli epigrammi greci di Assisi. Acc. Naz. Lincei: Bollettino dei Classici, 3, 2, pp. 196-217, 1981.

Postille ai Carmina Asisinatia. Bollettino dei Classici ( $3^{\text {rd }}$ s.), 8, pp. 37-68, 1987.

MET (The Metropolitan Museum of Art), Rogers Fund, inv. no. 20.192.17.

MICHEL, D. La Casa dei Cei. Munich: Hirmer Verlag, 1990.

MONELLA, P. Procne e Filomela. Dal mito al simbolo letterario. Bologna: Patron Editore, 2005.

MORRICONE MARTINI M. L.; SCRINARI S. M. V. Mosaici antichi in Italia regione prima Antium. Roma: Roma Istit. Poligr. dello Stato, 1975.

PAILLER, J. M. Attis, Polyphéme et le thiase bachique: quelques représentations méconnues, MélRome, 83, 1971.

PETRAIN, D. Homer, Theocritus and the Milan Posidippus (P.Mil.Vogl. VIII 309, Col. III.28-41). The Classical Journal, 98, 4, pp. 359-388, 2003.

PRIOUX, É. Le Poète, l'artiste et le collectionneur. Naissance d'un discours sur l'art dans l'épigramme hellénistique et romaine (III ${ }^{e}$ s. av. J.-C. - II ${ }^{e}$ s. ap. J.-C.), PhD Diss., Université de Nanterre, 2004.

Réflexions autour de quatre interprétations symboliques de l'image de Narcissse. In: ROUILLARD, P. (org.). L'Eau: enjeux, usages et représentations. Colloques de la Maison René-Ginouvès, 4, pp. 333-346, 2008 (a).

Petits musées en vers: épigramme et discours sur les collections antiques, «L'Art \& l'Essai» n5, Paris, 2008 (b). 
REINARCH, S. Répertoire de reliefs grecs et romains. Paris: E. Leroux, 1912.

Repertoire de peintures grecques et romaines. Paris: E. Leroux, 1922.

ROSATI, G. Narciso o l'illusione dissolta (Ovidio, Metam. III, 339-510). Maia, 28, pp. 83-108, 1976.

_. Narciso e Pigmalione: Illusione e Spettacolo nelle Metamorfosi di Ovidio Florence: Sansoni, 1983.

SEG (Supplementum Epigraphicum Graecum), XXX, 1135-1144, Amsterdam, 1025-.

SMITH, P. L. Vergil's Avena and the Pipes of Pastoral Poetry. Transactions and Proceedings of the American Philological Association, 101, pp. 497-510, 1970.

SQUIRE, M. Image and Text in Graeco-Roman World. Cambridge: Cambridge University Press, 2009.

STRAZZULLA, M. J. Assisi. EAA Suppl. II, 488, Abb. 555, 1994.

THOMAS, R. F. Proteus the Sealherd (Callimich. SH. Frag 254.6). CP 81, p. 319, 1986. TOUCHEFEU-MEYNIER, O. Polyphemos. Lexicon Iconographicum Mythologiae Classicae. VIII/1 (supplementum), pp. 1011-1019, 1997.

TOULOUPA, E. Prokne et Philomela. LIMC VII/1, pp. 527-29, 1994.

TRAN TAM TINH. Catalogue des peintures romaines (Latium et Campanie) du musée du Louvre. Paris: Editions des musees nationaux, 1974.

TURCAN, R. Les sarcophages romains à represéntations dionysiaques. Paris: E. De Boccard, 1966.

VEYVE, P. L'élégie érotique romaine. Paris: Le Seuil, 1983. 